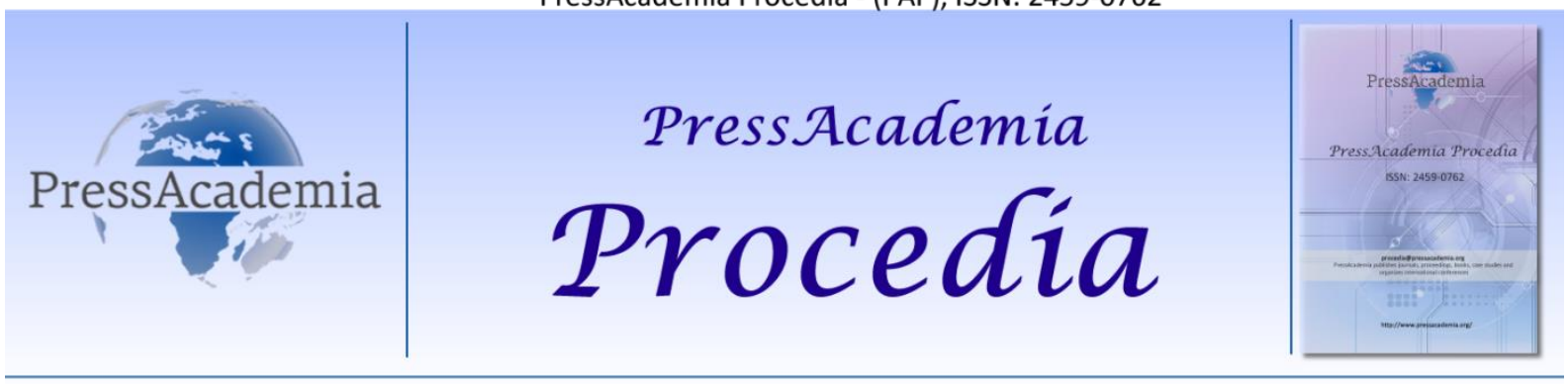

2nd World Conference on Technology, Innovation and Entrepreneurship

May 12-14, 2017, Istanbul, Turkey. Edited by Sefer Şener

\title{
STRATEGIES FOR THE INVOLVEMENT OF NURSES AS ENTREPRENEURS IN HEALTHCARE
}

\author{
DOI: 10.17261/Pressacademia.2017.514 \\ PAP-WCTIE-V.4-2017(6)-p.39-42
}

\author{
Nuray Turan ${ }^{1}$, Nurten Kaya ${ }^{2}$, Gulsun Ozdemir Aydin ${ }^{3}$ \\ ${ }^{1}$ Istanbul University, Florence Nightingale Nursing Faculty, Department of Fundamentals of Nursing. Turkey.nkaraman@istanbul.edu.tr \\ ${ }^{2}$ Istanbul University, Health Sciences Faculty, Department of Midwifery, Turkey. nurka@istanbul.edu.tr \\ ${ }^{3}$ Istanbul University, Florence Nightingale Nursing Faculty, Department of Fundamentals of Nursing, Turkey. gulsunoz@istanbul.edu.tr
}

\begin{abstract}
Nowadays, entrepreneurship, which is a dynamic factor in all fields to improve the quality of human life, is gaining importance in the health care system with each passing day. This system, which has a very wide area,allows nurses to fulfill their contemporary roles and responsibilities as a professional.Nursing entrepreneurship has a multi-dimensional background.Unlike traditional nursing approaches,entrepreneurship has an important place among contemporary nursing roles and responsibilities. Entrepreneurship is an important source of innovation and creativity. Entrepreneurial nursing is based on the factors such as nursing services, health care products, legal services, health care services/political advice and publications. In this context, entrepreneurship in nursing is accepted in every field, and its recognition is increasing. Consequently, nurses are expected to be entrepreneurs as a change agent in the health care system. However, there are many factors that support and prevent nursing entrepreneurship. This review has been designed to describe the barriers of entrepreneurship in nursing and to present strategies for overcoming these barriers.
\end{abstract}

Keywords: Entrepreneurship, health care, contemporary roles and responsibilities, nurses JEL Codes: L21

\section{INTRODUCTION}

Nowadays, entrepreneurship has become one of the important factors playing a role in economic development with the rapid development of technology, the transition from the industrial society to the information society and the ease of access to information. In recent years, entrepreneurship has become increasingly important in the world and in our country. The facts that entrepreneurship increases employment in the developed and developing countries, provides economic development and increases the social and individual living standards are among the most important reasons for this situation (Ekici, 2016; Rahman and Day, 2014). Nowadays, the concepts of enterprise, entrepreneur and entrepreneurship have also come to the forefront in our country as well as all over the world in order to provide individual and social welfare and to increase the quality of life.

\section{THE CONCEPTS OF ENTERPRISE, ENTREPRENEUR AND ENTREPRENEURSHIP}

Although there are many definitions of enterprise, entrepreneurship and entrepreneur in the literature, the first definition of entrepreneurship and entrepreneur made by Richard Cantillon in 1755 is widely accepted (Korkmaz, 2012). Enterprise, which is a French-derived word "enterprender/ entrepreneur", refers to the state of going into action, starting and attempting to perform an action. Entrepreneur is used in the meaning of an enterprising person in such a situation. According to Cantillon, entrepreneur is defined as a person who organizes the business in order to make profit and undertakes the risks of the business. Entrepreneurship is defined as a concept that includes entrepreneurs' whole processes of taking risks, watching for opportunities, putting into practice and making innovation by devoting the necessary time and effort (Arslan and Şener, 2012; Öztürk et al., 2014; Taysı and Canbaz, 2014; Yılmaz and Sünbül, 2009). In the literature, entrepreneurship is also used in the meaning of working independently (self-employment) or starting to a work. Entrepreneurship aims to take advantage of the emerging opportunities or to create new opportunities. In this sense, 
entrepreneurship is a process for the creation and follow-up of opportunities independently of whether or not resources are controlled (Mungan, 2013). The concept of entrepreneurship has four main components. These are being innovative and creative, risk taking, pioneering and competitive thinking. Being innovative and creative refers to seek creative, unusual and new solutions to the problems and requirements. Risk is a decision-making feature and defines the uncertainty of the outputs to be achieved as a result of the implementation of decisions. Pioneering refers to take responsibility and go into action by taking the necessary decisions instead of following others. Competition creates a healthy environment both for institutions and consumers. Competition ensures that entrepreneurs produce quality products, work efficiently and are consumer-oriented in order to be able to exist (www.hbogm.meb.gov.tr). Although entrepreneurship entering into the economy literature starting from the eighteenth century has showed its effects for the implementation of technological developments, this concept has scarcely been included in other literatures (Taysı and Canbaz, 2014). However, entrepreneurship emerging with the combination of bio-physiological, socio-cultural, psychological and technological items develops by the fact that individuals have a high entrepreneurial motivation and entrepreneurial spirit and enthusiasm for entrepreneurial activities (Korkmaz, 2012). Therefore, entrepreneurship should be the field of interest of other fields, especially health and education, not only the field of economy.

\subsection{Importance of Entrepreneurship}

Entrepreneurship initiates and develops change in the structure of business administration and society, thus it contributes to the growth of entrepreneurial activities as well as playing important roles in terms of the economic progress and social development of a country (Ekici, 2016). Entrepreneurship has a strategic significance for developing economies. Because the ways to gain profit, to activate the unused potential and to create new business districts are to encourage entrepreneurs (Korkmaz, 2012; Yılmaz and Sünbül, 2009). Entrepreneurship also involves many important factors such as the increase in production, productivity and income level, the developments in health care system, developments in education, developments in knowledge and technology (Gözek, 2006).

In particular, important countries that have realized that entrepreneurship act as an important engine for economic growth, innovation and competitiveness have increased the number of entrepreneurs. The United States is the most important country among them.

\subsection{Characteristics of Entrepreneur}

To be able to adapt to the competitive environment and survive advantageously along with the technology, that has made progress at an unprecedented pace in the globalizing world, depends on the degree of economic development. In this sense, one of the dynamic elements that keep the economies alive is entrepreneurs (Taysı and Canbaz, 2014). Entrepreneurs play a key role in recognizing the requirements of the community and turning them into investment and social welfare as an added value. Therefore, entrepreneurs should have certain characteristics in order to become entrepreneurs. There is a close relationship between the success in entrepreneurship and the personal characteristics of entrepreneurs (Yılmaz and Sünbül, 2009).

Unlike the other people, entrepreneurial individuals have characteristics such as having a strong desire for success, being devoted to freedom, being planned, being able to take risks, to take responsibility, being dynamic, having a rich subconscious and imaginative ability, being open to innovation and change, and having personal mission and vision. Entrepreneurs without these characteristics cannot be successful (Arslan and Şener, 2012; Mungan 2013; Öztürk et al. 2014; Yılmaz and Sünbül, 2009).

The most important element that leads the individual to become an entrepreneur and makes him/her successful in this regard is the entrepreneurial capacity. People prove their abilities or show their creativity through this capacity they have, and thus they can manage their professional life (Öztürk et al., 2014).

Along with the fact that entrepreneurship has increasingly become more important in societies, what the factors that trigger the tendency of entrepreneurship in individuals are has become an issue of concern in academia. In this context, the personal, demographic and environmental factors affecting the entrepreneur's personality and entrepreneurial personality have been primarily emphasized (Ekici 2016; Karabulut 2009). These factors can be sorted as age, gender, education, educational status of mother and father, the birth order in the family, the occupational ideal, the presence of entrepreneur in the family and the income level of the family (Ekici, 2016; Akşit, 2003; Avşar, 2007).

According to Russel (1997), entrepreneurial activities play a key role in the emergence of new enterprises. On the other hand, socio-cultural factors can support or inhibit the activities of entrepreneurs. Social values, beliefs and norms are the starting points for the emergence of new initiatives. Individuals' perceptions on entrepreneurship are formed in this environment where they exist. Therefore, the socio-cultural and environmental dimensions of the individual directly affect the entrepreneurship and entrepreneurship practices. 


\section{NURSING AND ENTREPRENEURSHIP}

The health care system is one of the most dynamic systems in terms of service delivery. In particular, the rapidly increasing population activates the entrepreneurs in this field and prompts for different pursuits to provide quality care services in the health care system. As a consequence, entrepreneurship is gaining importance in the healthcare system with each passing day. (Öztürk et al.,2014).

This system, which has a very wide scope, allows nurses to fulfill their contemporary roles and responsibilities as a professional. However, as a result of the wrong policies applied for the effective use of healthy human power, the need for qualified professional health care manager could not be foreseen at the right time, as in the nursing profession, so this requirement has not been met. However, nurses constitute the members of the health care team with whom the healthy/sick person establishes the most frequent and long-term communication within the interdisciplinary structure of the health service delivery (Dayhoff and Moore, 2005; Dolu et al., 2016).

Nursing entrepreneurship has a multi-dimensional background. Unlike traditional nursing approaches, entrepreneurship has an important place among contemporary nursing roles and responsibilities (Dolu et al. 2016). In terms of nursing profession, nursing is defined as "the nurse's supervision regarding the patient care and practices" (ICN, 2004). Entrepreneur nurse is the person who directly provides nursing services such as care, education, research, management or counseling (Arslan and Şener, 2012). One of the identified segments of entrepreneurship is the nurse entrepreneur, where an autonomous independent nurse works directly with patients in a private practice setting (Smith 1996). It is known that nurse entrepreneurs suggestion is a cost-effective alternative for specific types in health care services (Cook, 2005).

Entrepreneurship improves the skills of nurses in the working environment and contributes to their personal lives. Entrepreneurship is also an important part of decision making in the process of career planning and development of nurses (Arslan and Şener, 2012).

Nowadays, rapidly developing medical and technological developments as well as the capital limitations in front of nursing entrepreneurship, inexperience in business, inadequate professional support, the attitudes of other health professionals and legal barriers make innovation compulsory and create an opportunity for nursing entrepreneurship (Bemis, 2008; Dolu et al., 2016; Austin et al., 2006).

\subsection{Characteristics of Entrepreneur Nurse}

Entrepreneurship is an important source of innovation and creativity (Yelkikalan et al., 2010). The belief that human is not born as an entrepreneur and that the individuals has been provided with the existing potential by cultural, sociological, psychological, political and economic environmental factors has become widespread while the discussions of "Is entrepreneurship inherent or does it come into existence afterwards?" has been made (Bozkurt, 2011).

When the literature is examined, it is seen that the entrepreneurial aspects of nurses are affected by their individual (strong personality and the power of faith, being able to take risks, being creative and enterprising, being able to dream, to be honest, reliable, patient and enthusiastic, to be planner and organizer, to be able to foresee the future) and occupational characteristics (experience, knowledge, communication skills, reconciliation, time management). To develop a new product to improve patient care and to market it can be given as an example for entrepreneur nursing (Arslan and Şener, 2012).

The roles and responsibilities such as nursing services, health care products and appliances, legal services, health services/political consultancy and political publications are on the basis of entrepreneur nursing. In this context, the concept of entrepreneurship in nursing is accepted in all fields and its recognition is increasing (Arslan and Şener, 2012; Wilson et al., 2003).

Nowadays, entrepreneur nurses are in various positions outside the hospital environment. Counseling works, training companies, home/health companies/agents, assistance-based life and day care institutions for adults, child care centers, community clinics, durable medical equipment companies, writing-publishing work places and health care product companies are the main fields among them (Arslan and Şener, 2012).

\section{CONCLUSION}

The development of entrepreneurship includes the dissemination of entrepreneurship trainings and the development of entrepreneurship characteristics of individuals. Therefore, it is thought that the individual entrepreneurship levels of nurses and the factors affecting nurse entrepreneurship should be determined in the development of health care services and in the formation of innovative programs. In this context, it is recommended to; develop an entrepreneurial and aggressive nurse student profile as an important model, regulate the curriculum teaching practices in nursing faculties/colleges with an understanding that supports innovation, organize in-service programs, trainings, seminars and conferences on entrepreneurship for nurses. 


\section{REFERENCES}

Akşit, G. (2003). Farklı Kültürlerde Girişimcilik Niyeti ve Üniversite Öğrencilerine Yönelik Karşılaștırmalı Bir Araştırma [The Study of the Entrepreneur Inteation in Different Coltures: An Application to University Student] (yayınlanmamış yüksek lisans tezi). Akdeniz Üniversitesi/Sosyal Bilimler Enstitüsü, Antalya.

Arslan, H, Şener DK. (2012). Hemşirelikte yeni ve önemli bir kavram: girişimcilik [A new and ımportant concept in nursing: entrepreneurship]. i.Ü.F.N. Hem. Derg 20(2): 140-145.

Austin, L., Luker, K. Roland, M. (2006). Clinical nurse specialists as entrepreneurs: constrained or liberated. J Clin Nurs 15(12): 1540-1549.

Bemis, P.A. (2008). Obstacles to nurse entrepreneurship. RN 71(12): 21-22.

Boore, J. Porter, S. (2011). Education for entrepreneurship in nursing. Nurse Educ Today 31(2): 184-191.

Bozkurt, Ö.Ç. (2011). Dünyada ve Türkiye'de Girişimcilik Eğitimi: Başarılı Girişimciler ve Öğretim Üyelerinden Öneriler [Entrepreneurship Education in the World and in Turkey: Proposals from Successful Entrepreneurs and Faculty Members] Ankara: Detay Anatolia Akademik Yayıncılık Ltd. Şti.

Cook, R. (2005). Community nursing in the 21st century: Who, where, what, how? British Journal of Community Nursing 10(7): $306-311$.

Dayhoff, N.E., Moore, PS. (2005). CNS Entrepreneurs: innovators in patient care. Nurse Practitioner, 6-8.

Dolu, İ.Ç, Temuçin, E.D.,Özkan,H.A. (2016).Hemşirelik öğrencilerinin girişimcilik düzeyleri ile bazı ilişkili faktörlerin değerlendirilmesi. [Assessment of the entrepreneurial characteristics and some related factors of nursing students] JED/GKD 11(2): 293-315.

Ekici, E. (2016). Üniversite Öğrencilerinin Girişimcilik Eğilimini Belirlemede Planlanmış Davranışlar Teorisi ve Girişimcilik Eğitiminin Rolü. [Measurement of University Students' Entrepreneurship Intention : The Role of the Theory of Planned Behavior and Entrepreneurship Education] (Yayınlanmamış yüksek lisans tezi), Çukurova Üniversitesi/ Sosyal Bilimler Enstitüsü Yönetim ve Organizasyon Anabilim Dalı, Adana.

Gözek, S. (2006). Girişimci Adayının Özellikleri, Girişimcilik Eğilimleri ve Girişimci Adayına Sağlanan Destekler, [The Entrepreneur Candidate's Specialities, their Entrepreneur's Propensity and Supports which is Provided for the Entrepreneurs] (Yayınlanmamış yüksek lisans tezi), Sütçü İmam Üniversitesi/Fen Bilimleri Fakültesi, Kahraman Maraş.

http://hbogm.meb.gov.tr/aol/kitaplar/aol/2014/girisimcilik1/unite1.pdf.

International Council of Nurses (ICN) (2004). Guidelines on the Nurse Entre/Intrapreneur Providing Nursing Service. Geneva, 1-33.

Karabulut, A.T. (2009). Üniversite öğrencilerinin girişimcilik özelliklerini ve eğilimlerini belirlemeye yönelik bir araştırma [A study to determine the entrepreneurial characteristics and intentions of college students]. Marmara Üniversitesi i.i.B.F. Dergisi 26 (1): 1-18.

Korkmaz, O. (2012). Üniversite öğrencilerinin girişimcilik eğilimlerini belirlemeye yönelik bir araştırma: Bülent Ecevit Üniversitesi örneği [Research on determining the entrepreneurialism inclination of university students: Bülent Ecevit University example]. Afyon Kocatepe Üniversitesi, iiBF Dergisi, XIV(II): 209-226.

Mungan, S. (2013). Kadın Girişimcilik Değerleri Ile Kadın Girişimcilik Algısı Arasındaki İlişkide Girişimcilik Eğitimlerinin Rolü [Role of Entrepreneurship Trainings on the Relations Between Woman Entrepreneurship Values and Woman Entrepreneurship Perception] (Yayınlanmamış yüksek lisans tezi), Marmara Üniversitesi/Sosyal Bilimler Enstitüsü İşletme Anabilim Dalı Yönetim ve Organizasyon Bilim Dalı, Mersin.

Öztürk, Y.E., Köksal, O., Kıraç, R. (2014). Sağlık yönetimi bölümü öğrencilerine yönelik girişimcilik ölçeğinin geliştirilmesi [Development of entrepreneurship scale for students of health management department]. International Journal of Human Sciences, 11(2): 582-597.

Smith, S. (1996). Independent nurse practitioner: Advanced nursing practice in Brisbane. Australia. Nursing Clinics of North America. 31(3): 549-564.

Taysı, K., Canbaz, S. (2014). Önlisans öğrencilerinin girişimcilik özelliklerini ve eğilimlerini belirlemeye yönelik bir araştırma [A research on identifying enterpreneurship qualities and tendencies of the students of associate degree]. Electronic Journal of Vocational Colleges. 59-67.

Wilson, A., Averis, A. Walsh, K. (2003). The influences on and experiences of becoming nurse entrepreneurs: a Delphi study. International Journal of Nursing Practice. 9(4): 236-245.

Yelkikalan, N., Akatay, A., Yıldırım, H.M., Karadeniz, Y., Köse, C. Koncagül, Ö. (2010). Dünya ve Türkiye üniversitelerinde girişimcilik eğitimi: karşılaştırmalı bir analiz [Entrepreneurship Education in World and Turkish Universities: A Comparative Analysis]. KMÜ Sosyal ve Ekonomik Araştırmalar Dergisi, 12(19): 51-59.

Yılmaz, E., Sünbül, A.M.(2009). Üniversite öğrencilerine yönelik girişimcilik ölçeğinin geliştirilmesi [Developing scale of university students entrepreneurship]. Selçuk Üniversitesi Sosyal Bilimler Enstitüsü Dergisi. 21: 195-203. 